\title{
Note
}

\section{The relationship between calcium and phosphorus retention in young calves and metacarpal radiographic photometry}

\author{
S. LANDAU *, U. BARGAI **, Zafrira NITSAN ***, \\ A. BEN ASHER * and I. NIR **** \\ *Extension Service, Ministry of Agriculture, Rehovot 76262, Israel \\ *: HaHaklait, Zora, Israel \\ *** Agricultural Research Organization, the Volcani Center, \\ Bet Dagan 50250, Israel \\ ***** The Hebrew University of Jerusalem, Faculty of Agriculture, \\ Rehovot 76262, Israel
}

\begin{abstract}
Summary
An experiment was carried out to study the relationship between calcium and phosphorus retention and bone density of the third and fourth metacarpal bones in the young calf over a wide range of $\mathrm{Ca}$ and $\mathrm{P}$ retention. Bone density was evaluated by spectrophotometry of radiographs. At the lateral cortex, bone density was found to be positively correlated to calcium retention $(\mathrm{P}<0.05)$, phosphorus retention $(\mathrm{P}<0.01)$ and calcium concentration in blood plasma $(\mathrm{P}<0.05)$; at the medial cortex or dorsal longitudinal sulcus, it was correlated to calcium and phosphorus retention to a lesser extent. Radiographic spectrophotometry of the third and fourth metacarpal bones thus seems to be a prospective useful and non destructive method for evaluating bone mineralization in young calves.
\end{abstract}

Key words : calcium, phosphorus, bone mineralization, radiography, calves.

\section{Introduction}

There is a great discrepancy between definitions of $\mathrm{Ca}$ and $\mathrm{P}$ requirements in the young calf : recommendations vary from $4.5 \mathrm{~g} \mathrm{Ca}$ and $3.2 \mathrm{~g} \mathrm{P} /$ day (NRC, 1971) to $9.0 \mathrm{~g} \mathrm{Ca}$ and $6.0 \mathrm{~g} \mathrm{P} /$ day (NRC, 1978), for calves weighing $50 \mathrm{~kg}$ and gaining $400 \mathrm{~g} / \mathrm{d}$. Weaned calves have been shown to gain equally on diets containing $16.2 \mathrm{~g}$ $\mathrm{Ca}$ and $11.7 \mathrm{~g} \mathrm{P}$ or $8.2 \mathrm{~g} \mathrm{Ca}$ and $5.6 \mathrm{~g} \mathrm{P}$, the main difference being bone mineral composition : high $\mathrm{Ca}$ and $\mathrm{P}$ diets induced higher concentrations of $\mathrm{Ca}$ and $\mathrm{P}$, expressed by higher ash content, especially in the long bones (Gueguen \& MATHIEU, 1965). Non destructive methods to assess bone density can be of great help in long-term experiments to define the optimal rate of bone calcification. Direct photon absorption of the radius and ulna in dogs, yielded mineral densities correlated to $\mathrm{Ca}$ and $\mathrm{P}$ concentrations in their diets (WENTWORTH et al., 1971). 
An in vivo ultrasonic method was used to monitor alterations in midshaft metacarpal density of Angus cows and heifers fed low or high $\mathrm{Ca}$ diets (Bokman et al., 1983). The calcification of long bones in piglets was determined by measuring the width of the radius and ulna diaphysis in radiographs, using a Vernier microscope (BLAIR \& BENZIE, 1964).

The distal metacarpal epiphysis is one of the most active bones in the young growing calf. As expected, lack of $\mathrm{Ca}$ will manifest itself in this area, in reduced bone density due to non-mineralized osteoids and widening of the radiolucent epiphyseal plate. Thinning of the cortex may also be noted.

Radiographic density of the equine third metacarpal as estimated by photometry was related to the ash concentration in this bone (MEAKIM et al., 1981).

Since it is known that various $\mathrm{Ca}$ and $\mathrm{P}$ sources different $\mathrm{Ca}: \mathrm{P}$ ratios (Roy, 1980) and interferences with organic nutrients (RAVEN, 1967 ; LANDAU, 1982) may affect $\mathrm{Ca}$ and $\mathrm{P}$ availability, it is proposed that $\mathrm{Ca}$ and $\mathrm{P}$ retention be the basis for establishing adequacy of a standardized method to assess bone mineralization in the calf. In the present work the relationships among metacarpal radiographic photometric density, $\mathrm{Ca}$ and $\mathrm{P}$ retention, and $\mathrm{Ca}$ and $\mathrm{P}$ concentration in blood plasma were studied.

\section{Material and methods}

Two-week-old-Israeli-Friesian bull calves were allotted to two blocks of six pairs, using an «at random block» design, according to body weight, and kept in individual metabolic pens with wooden slatted floors throughout the 39 days of the experiment. They were pail-fed $400 \mathrm{~g} / \mathrm{d}$ milk replacer and pair-fed amounts of starter concentrate, either in a dry form (DC) (six calves) or nipple-fed in a liquid form (LC) (six calves) : each LC calf was suckled with the same amount of concentrate as consumed ad lib. by his DC counterpart on the former day; the liquid concentrate was prepared by homogenizing $200 \mathrm{~g}$ pelleted starter concentrate with lukewarm water of known mineral content in an homogenizer (Ultraturrax, Ikawerk, Germany) and diluted to 1 liter : it was eagerly suckled by the LC calves. Feeding concentrates in a liquid form is associated with lower absorption of $\mathrm{Ca}$ and $\mathrm{P}$ (LANDAU, 1982), thus the experiment was designed to obtain a wide scale of $\mathrm{Ca}$ and $\mathrm{P}$ retention. The calves consumed $4.41 \pm 0.08 \mathrm{~g} \mathrm{Ca} / \mathrm{d}$ and $5.38 \pm 0.17 \mathrm{~g} \mathrm{P} / \mathrm{d}$ (mean $\pm \mathrm{SE}$ ) as compared with $4.5 \mathrm{~g} / \mathrm{d}$ and $3.2 \mathrm{~g} / \mathrm{d}$, respectively, calculated from the recommendations of NRC (1971) or $9 \mathrm{~g} / \mathrm{d}$ and $6 \mathrm{~g} / \mathrm{d}$, respectively, recommanded by NRC (1978). After a 12-day adjustment period, quantitative collection of the excreta was performed as described before (BEN-ASHER, NITSAN \& NIR, 1981) during a 4-day period. Blood was sampled twice from the jugular vein of each calf. The pooled faeces of each calf were homogenized with an equal weight of distilled water and dryashed $\left(600{ }^{\circ} \mathrm{C}\right.$ for $\left.4 \mathrm{~h}\right)$. The ash was dissolved in $5 \mathrm{~N} \mathrm{HCl}$ and analyzed for $\mathrm{Ca}$ with the calcein reagent after suitable dilution, using an Automatic Calcium Analyzer (Precision Systems, Sudbury, MA). The $\mathrm{Ca}$ concentration in feeds was determined by the same procedure; $\mathrm{Ca}$ in drinking water, urine and blood plasma was analyzed directly (without ashing) by the same method. 
Phosphorus in the feeds, faeces and urine was determined by Technicon Autoanalyzer (Industrial Meth., 18-69 W), after digestion with sulphuric acid and suitable dilution. On the 17 th day, the calves were sedated by intramuscular injection of $1 \mathrm{ml}$ Rompun (Bayer) and their left forelegs were radiographed. The third metacarpal bone was very suitable for radiography, being a long bone, easily accessible and easily manipulated for anterior-posterior and lateral views to enable the examination of the growth plate and cortexes. All radiographs were made in the same manner, using a Profexray portable unit (25 MA Model) ; exposure data -5 MAS ; 65 useful KVP (setting of $103 \mathrm{kV}$ at $5 \mathrm{MA}$ ); $75 \mathrm{~cm}$ F.F.D.

The anterior-posterior views of the third and fourth metacarpal bones were radiographed simultaneously with an aluminium stepwedge, used as a reference standard for photometric estimation of bone mineral density (МЕакім et al., 1981). All radiographs were scanned at the same site (midshaft of the third-fourth metacarpal bone), using a Uvikon 820 (Kontron Spectrophotometer) at $540 \mathrm{~nm}$ wavelength, including a longitudinal scan of the aluminium stepwedge. The proportion of light transmission was established.

The data were subjected to analysis of variance and linear correlations were determined (STEEL \& TORIE, 1960). In addition, regression equations were submitted to best-fit analysis (NiE et al., 1975).

\section{Results and discussion}

A typical radiograph and photometric image is shown in fig. 1. The three peaks, $\mathrm{A}, \mathrm{B}$ and $\mathrm{C}$, represent points of greatest bone density on the lateral cortex, dorsal longitudinal sulcus and medial cortex, respectively. One calf was radiographed three times in order to estimate the repeatability of the procedure. The coefficients of variation were found to be $0.037,0.069$ and 0.056 for peaks $A, B$ and $C$, respectively.

In addition, high correlations were obtained in the transmittance values between the peaks : A vs. B, $\mathrm{r}=0.86$; A vs. C, $\mathrm{r}=0.97$; B vs. $\mathrm{C}, \mathrm{r}=0.96(\mathrm{p}<0.001)$, which indicates that the basis of the method is sound. The values of $A, B, C$ (densities expressed in mm aluminium), $\mathrm{Ca}$ and $\mathrm{P}$ retention ( $\mathrm{CaR}$ and $\mathrm{PR}$ ), and $\mathrm{Ca}$ and $\mathrm{P}$ concentration in blood plasma ( $\mathrm{CaPl}$ and $\mathrm{PPl}$ ) are shown in table 1 . Bone mineral density was lower in the LC calves than in the DC ones (significant for the pooled data). Concurrently, the $\mathrm{Ca}$ and $\mathrm{P}$ retentions were also lower in the LC than in the DC calves $(\mathrm{p}<0.05)$.

Correlation coefficients and regression equations are shown in fig. 2, 3 and 4 . The corrclations between $\mathrm{Ca}$ and $\mathrm{P}$ retention and bone density at peaks $\mathrm{A}$ and $\mathrm{C}$ were found to be statisticaly significant (fig. 2 and 3). This is in accord with the results of Miskim et al. (1981), who found that bone density at lateral cortex was best related to ash content in the equine third metacarpal, as determined by ashing.

A significant relationship was found between total $\mathrm{Ca}$ in blood plasma and bone density at cach of the three peaks (fig. 4); CaPl was not correlated to $\mathrm{Ca}$ or $\mathrm{P}$ retention and total inorganic $P$ in blood plasma was not correlated to any of the other parameters; morcover, it seems that when calcemia exceeds $9 \mathrm{mg} / 100 \mathrm{ml}$, no dependence can be found betwcen bone density and plasma $\mathrm{Ca}$ concentration (fig. 4). 


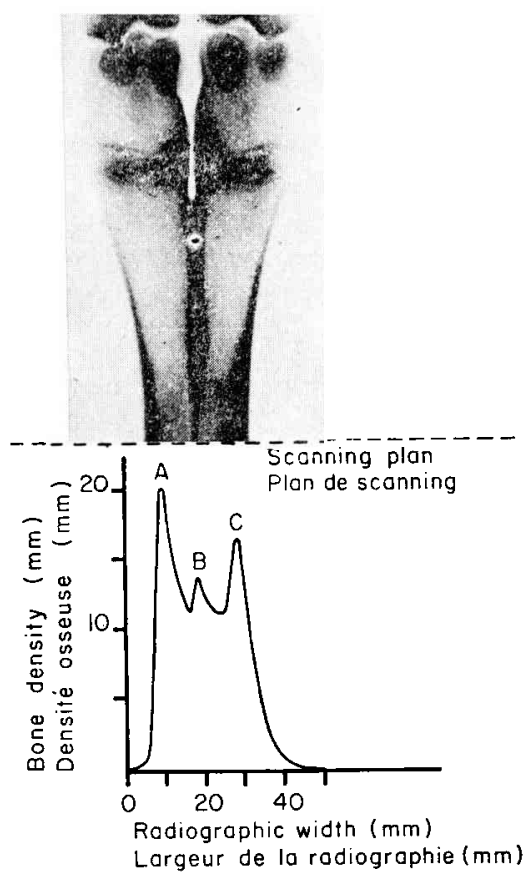

FIG. 1

Photometric image of a calf metacarpal radiograph showing three peaks of density $(A, B, C)$, expressed in aluminium units ( $\mathrm{mm}$ Al).

Image photomètrique d'un métacarpe de veau illustrant 3 pics de densité $(A, B, C)$ exprimés en équivalence d'aluminium ( $\mathrm{mm} \mathrm{Al}$ ).

\section{TABLE 1}

Values of bone mineral densities at lateral cortex (A), dorsal longitudinal sulcus $(B)$ and medial cortex $(C)$, calcium retention $(C a R)$, phosphorus retention (PR),

blood plasma calcium (CaPI) and phosphorus (PPl) concentrations of calves fed milk replacer and concentrate in a dry (DC) or liquid form (LC).

Valeurs de densité minérale osseuse au cortex latéral $(A)$, au sulcus longitudinal dorsal (B) et au cortex medial $(C)$, rétention du calcium (CaR) et du phosphore (PR), calcium plasmatique $(\mathrm{CaPl})$ et phosphatémie (PPl) de veaux nourris de lait de remplacement et de concentré distribué sous forme solide (DC) ou liquide $(L C)$.

\begin{tabular}{|c|c|c|c|}
\hline & $\begin{array}{c}\mathrm{DC} \\
(\text { mean }+\mathrm{SE})\end{array}$ & $\begin{array}{c}\mathrm{LC} \\
(\text { mean }+\mathrm{SE})\end{array}$ & $\mathrm{p}<$ \\
\hline $\mathrm{A}(\mathrm{mm} \mathrm{Al})$ & $26.4+1.5$ & $23.4+1.6$ & NS \\
\hline $\mathrm{B}(\mathrm{mm} \mathrm{Al}) \ldots \ldots$ & $22.3+1.6$ & $19.8+1.2$ & NS \\
\hline $\mathrm{C}(\mathrm{mm} \mathrm{Al})$ & $24.4+1.4$ & $21.6+1.4$ & NS \\
\hline $\mathrm{A}, \mathrm{B}, \mathrm{C}(\mathrm{mm} \mathrm{Al})$ pooled & $24.4+1.6$ & $21.6+1.4$ & 0.02 \\
\hline $\mathrm{CaR}(\mathrm{g} / \mathrm{d}) \ldots \ldots \ldots \ldots$ & $2.93+0.20$ & $2.44+0.14$ & 0.05 \\
\hline $\operatorname{PR}(g / d)$ & $2.07+0.24$ & $1.58+0.18$ & 0.05 \\
\hline $\mathrm{CaPl}(\mathrm{mg} / 100 \mathrm{ml})$ & $8.91+0.23$ & $8.74+0.21$ & NS \\
\hline PPl (mg/100 ml) & $6.93+0.28$ & $6.96+0.25$ & NS \\
\hline
\end{tabular}




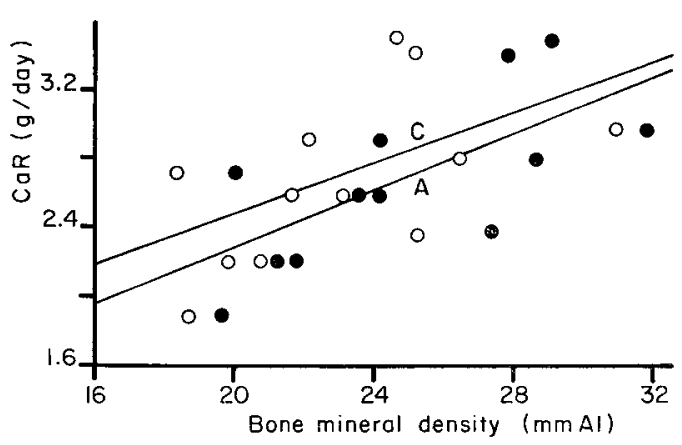

FIG. 2

Correlation between calcium retention (CaR) and bone mineral density at peaks $A(0)$ and $C(0)$.

Corrélation entre la rétention du calcium (CaR) et la densité minérale osseuse aux pics $A(0)$ et $C(0)$.

2.1. For peak A (pic $A$ ) $: \mathrm{r}=0.693 ; \mathrm{Y}=0.084 \mathrm{x}+0.596 ; \mathrm{p}<0.05$.

2.2. For peak $\mathrm{C}$ (pic $C$ ) $: \mathrm{r}=0,560 ; \mathrm{Y}=0.074 \mathrm{x}+0.987 ; \mathrm{p}<0.10$.

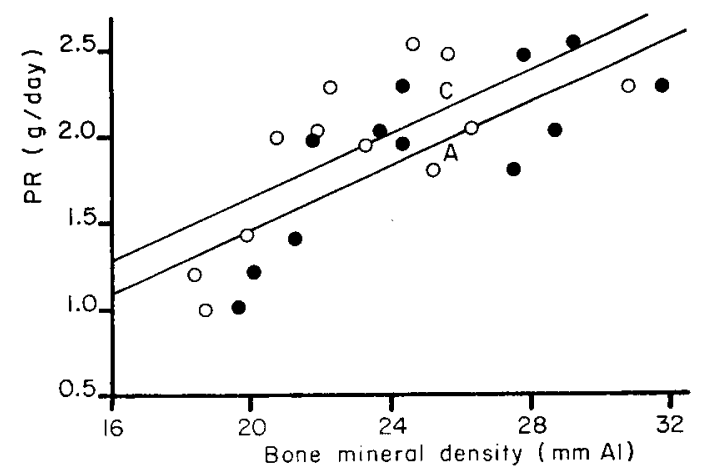

FIG. 3

Correlation between phosphorus retention (PR) and bone mineral density at peaks $A(\bullet)$ and $C(O)$.

Corrélation entre la rétention du phosphore (PR) et la densité minérale osseuse aux pics $A(\bullet)$ et $C(0)$.

3.1. For peak A (pic A) : $\mathrm{r}=0.768 ; \mathrm{Y}=0.093 \mathrm{x}-0.414 ; \mathrm{p}<0.01$.

3.2. For peak $\mathrm{C}$ (pic C) : $\mathrm{r}=0.690 ; \mathrm{Y}=0.092 \times-0.198 ; \mathrm{p}<0.05$. 


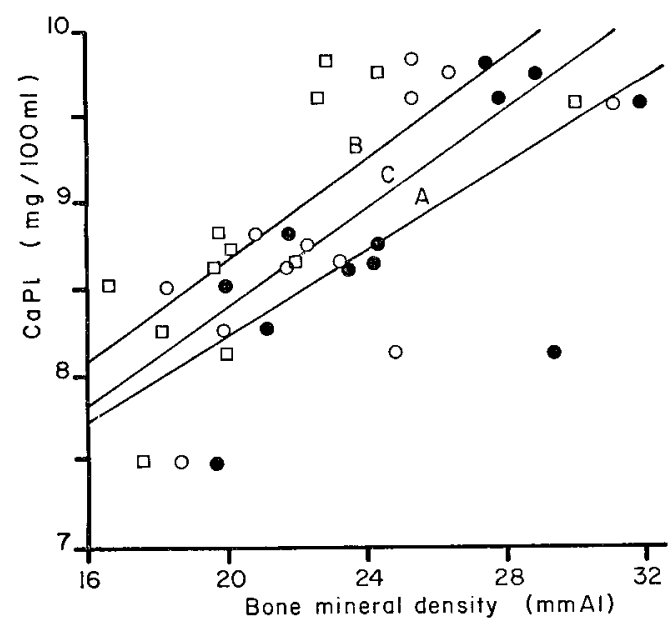

Fir. 4

Correlation between calcium concentration in blood plasma ( $\mathrm{Ca} \mathrm{Pl)}$ and bone mineral density at peaks $A(\bullet), B(O)$ and $C(\square)$.

Corrélation entre le calcium plasmatique (Ca Pl) et la densité minérale osseuse aux pics $A(\mathbf{0}), B(0)$ et $C$ ( $\square)$.

4.1. For peak A (pic A) : $\mathrm{r}=0.681 ; \mathrm{Y}=0.124 \mathrm{x}+5.75 ; \mathrm{p}<0.05$.

4.2. For peak $\mathrm{B}$ (pic B) $: \mathrm{r}=0.732 ; \mathrm{Y}=0.147 \mathrm{x}+5.73 ; \mathrm{p}<0.01$.

4.3. For peak $\mathrm{C}($ pic $C): \mathrm{r}=0.728 ; \mathrm{Y}=0.144 \mathrm{x}+5.50 ; \mathrm{p}<0.01$.

No improvement of the predictive values of the equations was obtained when a nonlinear model was used : therefore the linear equations are presented in fig. 2, 3 and 4. A linear relationship between humerus and femur ash content and $\mathrm{Ca}$ and $P$ retention was reported in a former study, carried out in calves up to 15 months of age, gaining $640 \mathrm{~g} / \mathrm{d}$. Ca and P retention in these calves was $10.9 \mathrm{~g} / \mathrm{d}$ and $8.0 \mathrm{~g} / \mathrm{d}$, respectively (GuLguen \& MATHIEU, 1965). The results of the cited study are compatible with those obtained in the present work.

It seems that determination of bone density by densitometry of X-ray photographs is a more objective procedure than measuring the width of bone cortexes on photographs as performed by BLAIR \& BENZIE (1964). The peaks of bone density (fig. 1, bottom) are clearly defined, whereas shadow projection of the bones may alter the accuracy of their width measurement.

\section{Conchusion}

Radiographic photometry of the third and fourth metacarpal bones of young calves can be used as a reliable method for evaluating bone mineralization. Better accuracy could be reached by photographing the metacarpal bones twice, at the 
beginning and the end of experimental period to eliminate residual variance which can be present prior to experiment, thus correlating the increase in bone density to $\mathrm{Ca}$ and $\mathrm{P}$ retention in the calves.

It seems also that this method has a potential in monitoring bone mineral changes in long-term experiments in bovines.

Reçu en février 1984. Accepté en janvier 1985.

\section{Résumé}

Etude de la relation entre la rétention du calcium et du phosphore et la densité osseuse des $3^{*}$ et $4^{*}$ métacarpes chez le jeune veau

La densité osseuse a été évaluée par spectrophotométrie de radiographie : mesurée au cortex latéral, elle s'est révélée être en corrélation positive avec la rétention du calcium $(\mathrm{P}<0,05)$, du phosphore $(\mathbf{P}<0,01)$ et la calcémie plasmatique $(\mathbf{P}<0,05)$; la densité mesurée au cortex medial ou au sulcus dorsal longitudinal a été en corrélation moins élevée avec la rétention du calcium et du phosphore. La spectrophotométrie radiographique des $3^{*}$ et $4^{\mathrm{e}}$ métacarpes semble être une méthode non-destructive et utile dans le futur pour évaluer la minéralisation osseuse des jeunes veaux.

Mots clés : calcium, phosphore, mineralisation osseuse, radiographie, veau.

\section{References}

Ben-Asher A., Nitsan Z., Nir I., 1981. Comparison of ruminal and post-ruminal digestion of a concentrate feed in the young calf. Reprod. Nutr., Develop., 21 (6 A), 999:-1007.

Blair A., Benzie D., 1964. Effect of level of dietary calcium and phosphorus on skeletal development in young pigs to $25 \mathrm{lb}$. live weight. Br. J. Nutr., 18, 91-101.

BoKman S.H., Evans J.L., Wohlt J.E., 1983. An in vivo ultrasonic technique to monitor alterations in bone density (abstr.). J. Anim. Sc., 57 (suppl. 1), 120.

Gueguen L., Mathieu C.M., 1965. Utilisation des éléments minéraux de la ration par le veau : influence du niveau de l'apport phospho-calcique. Ann. Zootech., 14, 231-245.

LANDAU S., 1982. Mineral balance in pre-weaned calves fed on different diets and different feeding regimes. M.Sc. thesis, The Hebrew University of Jerusalem.

Meakim D.Z., Ott E.A., Asquith R.L., Feaster J.P., 1981. Estimation of mineral content of the equine third metacarpal by radiographic photometry. J. Anim. Sci., 53, 1019-1026.

Nie N.H., Hull C.H., Jenkins J.G., Steinbrenner K., Bert D.H., 1975. Nonlinear Relationships. In : Statistical package for the social sciences, pp. 368-372. 2nd ed., McGraw Hill Book Company, New York.

N.R.C., 1971. National Research Council. Nutrient Requirements of Dairy Cattle, p. 26, The National Academy of Sciences, Washington, D.C.

N.R.C., 1978. National Research Council. Nutrient Requirements of Dairy Cattle, p. 36, The National Academy of Sciences, Washington, D.C.

RAVEN A.M., 1967. The nutrition value of milk replacer in terms of nitrogen and mineral retention. Scientific information no. 102, published by National Renderers Association, Rome.

Roy J.H.B., 1980. Nutrient requirement of the calf-major inorganic elements - calcium and phosphorus. In : The Calf, pp. 253-259. Butterworths, London.

Steel R.G.D., Torrie H.J., 1960. Principles and Procedures of Statistics, pp. 132-146, McGraw-Hill Book Co., New York, N.Y.

Wentworth R.A., Kaufelz F.A., Hiltz F.L., Schryver H., Sheffy B., Krook L.P., 1971. In vivo estimation of bone mineral content : a research and diagnostic technique for veterinary medicine. Am. J. Vet. Res., 32, 985-992. 